\title{
The clinical correlation of findings obtained by fine needle fenestration biopsy of the canine spleen with visible ultrasound changes
}

\author{
Martina Crnogaj'1, Iva Šmit ${ }^{1 *}$, Vladimir Mrljak ${ }^{1}$, Sara Došen ${ }^{3}$, Marko Hohšteter ${ }^{2}$, \\ Ivana Kišs ${ }^{1}$, Darko Grden ${ }^{1}$, Mirna Brkljačić ${ }^{1}$, and Jelena Gotić \\ ${ }^{1}$ Clinic for Internal Medicine, Faculty of Veterinary Medicine, University of Zagreb, Zagreb, Croatia \\ ${ }^{2}$ Department of Veterinary Pathology, Faculty of Veterinary Medicine, University of Zagreb, Zagreb, Croatia \\ ${ }^{3}$ Buba, Veterinary Clinic for Small Animals, Zagreb, Croatia
}

CRNOGAJ, M., I. ŠMIT, V. MRLJAK, S. DOŠEN, M. HOHŠTETER, I. KIŠ, D. GRDEN, M. BRKLJAČIĆ, J. GOTIĆ: The clinical correlation of findings obtained by fine needle fenestration biopsy of the canine spleen with visible ultrasound changes. Vet. arhiv 91, 537-546, 2021.

\section{ABSTRACT}

The medical records databases (March 2016 to March 2021) of the Faculty of Veterinary Medicine, University of Zagreb, were examined to determine the frequency and clinical relevance of cytological diagnoses from fine-needle fenestration biopsy (FNFB) of the spleen in dogs with visible ultrasound changes. Seventy-five dogs were divided into clinically relevant and irrelevant groups, according to the clinical relevance of the diagnosis. The incidence of clinically relevant diagnoses was 28/75 (37.3\%). Malignant diagnoses were over-represented $(23 / 28 ; 82.1 \%)$, followed by hemorrhages/hematomas $(3 / 28 ; 10.7 \%)$ and suppurative inflammation $(2 / 28 ; 7.1 \%)$. The most common malignancy was lymphoma $(12 / 28 ; 42.9 \%)$. There was no correlation between the ultrasound lesions examined and the relevant cytological diagnoses, except in cases of patchy echo texture $(\mathrm{P}=0.010)$. Lesion size greater than 1.74 $\mathrm{cm}$ had the highest sensitivity/specificity values $(91.3 \% ; 42.1 \%)$ with a significant area under the curve (AUC) of 0.68 $(\mathrm{P}=0.029)$ for predicting clinically relevant findings. The complication rate due to bleeding was $2 / 130(1.5 \%)$. In conclusion, splenic FNFB can be safely performed in dogs as it carries a low risk of development of complications. Specific ultrasonographic findings, such as patchy echo texture pattern, may increase the suspicion of the presence of neoplastic disease in the form of lymphoma. According to ROC analysis, lesion size greater than 1.74 increases the possibility of predicting clinically relevant findings.

Key words: dog; ultrasound; spleen; fine needle fenestration biopsy; cytology

\section{Introduction}

The spleen has several roles in the body: it is an important source of blood reserves, and has a function in blood filtration, humoral immune response, immune surveillance against microorganisms and, finally, plays a role in iron metabolism. Because of its position and function,

the spleen is involved in variety of disease processes, ranging from inflammatory processes, hyperplasia, to benign or malignant neoplastic processes (FIGUEIREDO et al., 2019). Ultrasonographically, it is possible to detect these disorders by various changes in the spleen, from splenomegaly to

\footnotetext{
*Corresponding author:

Assist. Prof. Iva Šmit, PhD, DVM, Clinic for Internal Medicine, Faculty of Veterinary Medicine, University of Zagreb, Heinzelova 55, 10000 Zagreb, Croatia, Phone: +385 12390 111, E-mail: ismit@vef.hr
} 
changes in homogeneity to various lesions/masses. Ultrasonography is a very useful tool for evaluating changes in the spleen, but it cannot determine the exact diagnosis (HANSON et al., 2001; RAMIREZ et al., 2002). Splenectomy remains the gold standard for evaluation of splenic lesions in veterinary medicine because it allows the collection of tissue samples large enough for histopathological diagnosis (BALLEGEER et al., 2007). However, splenectomy is an invasive diagnostic procedure requiring a surgical approach, and is performed under general anesthesia. Due to the nature of the procedure, complications are possible both during and after surgery. Even in uncomplicated surgery, animals undergoing splenectomy are more susceptible to conditions such as hypoxia, shock, sepsis, microbial infections, red cell parasitism, and cardiovascular complications (FIGUEIREDO et al., 2019). Furthermore, splenic lesions detected on ultrasonography often do not warrant immediate splenectomy. Therefore, less/non-invasive methods of diagnosis, such as FNFB (fine needle fenestration biopsy), are recommended (LEBLANC et al. 2009; GLIŃSKA-SUCHOCKA et al., 2013). As the results of FNFB and cytology are increasingly used in veterinary medicine, especially when looking at abdominal organs, they have become an active area of research worldwide in recent years.

Due to the lack of research, and the fact that the FNFB procedure and cytology are routinely used for diagnosing abdominal organ pathology at the Clinic for Internal Medicine of the Faculty of Veterinary Medicine, University of Zagreb, a retrospective study was conducted on dogs who had FNFB of the spleen performed as part of the standard diagnostic workup. The aim of this study was to show the frequency as well as the clinical relevance of cytological diagnoses (within a period of 6 years) from samples obtained using FNFB of the spleen in dogs with visible ultrasound changes. As part of the study, the correlation between ultrasound changes and cytological diagnosis was explored, as well as the incidence of complications following FNFB of the spleen in dogs and their severity.

\section{Materials and methods}

Animals. Since this is a retrospective study, we used the medical record databases of the Clinic for Internal Medicine of the Faculty of Veterinary Medicine, University of Zagreb, from the period between March 2016 and March 2021. The number of animals that underwent FNFB of the spleen in this period was 130 , while the number of animals that met the inclusion criteria was 75 . The authors proposed classification criteria as follows:

The inclusion criteria were:

changes in ultrasound findings of the spleen; FNFB of the spleen under ultrasound control; cytological analysis of spleen aspirates performed

by a pathologist from the Department of Veterinary Pathology, Faculty of Veterinary Medicine, University of Zagreb.

The exclusion criteria were:

cytological analysis of the spleen aspirate performed by other laboratories;

FNFB performed on the spleen because of mast cell neoplasia or lymphoma, with no change in ultrasound findings;

if multiple FNFBs were performed on the same patient, only the cytological diagnosis of the first FNFB was included in the study; non-diagnostic sample;

information collected from medical record databases included signalment (age and sex), the date of imaging and FNFB procedure, ultrasound findings, and cytological diagnoses.

Ultrasound. Abdominal ultrasound was performed in all the dogs in the study within two to three weeks before FNFB procedure. The indication to perform abdominal ultrasonography varied, and the ultrasound changes on the spleen were sometimes incidental. The spleen was reexamined just prior to the FNFB procedure. The hair was clipped, and the dogs were placed in right lateral recumbency. Ultrasound examination was performed using a MyLabTM 40 Vet (Esaote, Italy) with an 8-MHz microconvex transducer. The criteria used to classify changes in the ultrasound findings of the splenic parenchyma were: normal echo structure and homogeneous parenchyma, but enlarged spleen (radiographic confirmation of enlargement), altered echogenicity, heterogeneous 
parenchyma, the presence of numerous small hypoechoic nodules throughout the spleen causing a patchy echo texture (moth-eaten parenchyma), and the presence of lesions (single, multiple).

FNFB sampling and cytology. To minimize complications of the FNFB procedure (e.g., excessive bleeding), hematology and coagulation profiles were done for all dogs before the procedure. The procedure was performed on conscious dogs if they were calm and cooperative, otherwise they were sedated with methadone, midazolam and propofol. Hematology was performed with an ABC Automated Hematology Analyzer (Horiba Diagnostics, Montpellier, France), and coagulation profile with a QuickVet Analyzer and QuickVet cartridges (Zoetis, Denmark).

During the procedure, the clipped skin was prepared with chlorhexidine and ethanol. Fine needle fenestration biopsy of the spleen was performed under ultrasound guidance using $0.7 \mathrm{~mm}$ (22G) diameter needles. The FNFB method was used for sample collection due to the vascularity of the spleen (the needle is inserted into the affected organ area under USG control, and cytological material is collected by repeatedly rotating the needle). The FNFB is a non-aspiration technique, and according to research it is superior to other methods because samples have greater cellularity and less blood contamination (LEBLANC et al. 2009; GLIŃSKA-SUCHOCKA et al., 2013). To further avoid complications due to post FNFB bleeding, sampling from hypervascular and cystic lesions was avoided. The collected material was immediately placed on a slide and smears were performed using the "squash-prep" technique. An average of five slides per specimen $(4-6)$ were collected from the parenchyma and/or focal lesions. The smears were air dried and stained with May-Gruenwald Giemsa. As this was a retrospective study, all slides examined were once again reevaluated blindly by an experienced pathologist using light microscopy and standard diagnostic cytology, confirming the diagnosis with high interobserver agreement (RASKIN and MEYER, 2016). All patients were reexamined by ultrasound immediately and then again 30 minutes after the procedure to check for free fluid around the spleen. If no free fluid was found, they were discharged. Patients in which free fluid was detected were examined every 30 minutes for comparison of fluid volume.

Statistical analysis. Continuous data distribution was assessed using the Kolmogorov-Smirnov test and, depending on the results, appropriate nonparametric tests were used in the following analyses. Fisher's exact test was used to assess differences in categorical clinical variables, except in cases where there were combinations of cells greater than 2 by 2, in which Fisher-Freeman Halton's exact test was used. The Mann-Whitney U test was used to analyze differences in continuous variables between importance groups. ROC analysis was performed to discriminate the optimal lesion size diameter in predicting clinically relevant findings. The cut-off value was based on the optimal ratio of sensitivity to specificity (Youden index $J$ ). $P$ values less than 0.05 were considered significant. MedCalc ${ }^{\circledR}$ Statistical Software version 19.6.1 (MedCalc Software Ltd, Ostend, Belgium; https:// www.medcalc.org; 2020) was used in all statistical procedures.

\section{Results}

The medical records of client-owned dogs with cytological diagnosis were retrospectively reviewed, and 75 of 130 cases met the inclusion criteria in this study. The dogs were divided into two groups according to cytological diagnoses: the clinically irrelevant (47/75 dogs; 62.7\%) and the clinically relevant groups (28/75 dogs; $37.3 \%)$ (Table 2.). Cytological diagnoses were classified as clinically irrelevant or clinically relevant on the basis of their impact on the course of therapy. Clinically irrelevant cytological diagnoses did not affect the therapy, while clinically relevant cytological diagnoses had an impact on the course of therapy.

The signalment (breed, age and sex) according to the cytological diagnoses is summarized in Table 1. The breeds most represented were mixed breeds $(23 / 75 ; 30.6 \%)$, American Staffordshire terrier $(6 / 75 ; 8 \%)$ and Labrador retriever $(5 / 75 ; 6.7 \%)$. The breeds most represented in the clinically relevant group were the same: American Staffordshire terrier $(4 / 28 ; 14.3 \%)$, mixed breeds $(4 / 28 ; 14.3 \%)$ and Labrador retrievers $(4 / 28 ; 14.3 \%)$. 
M. Crnogaj et al.: Comparison of spleen fine needle fenestration biopsy diagnoses in dogs

Table 1. Signalment (breed, age, sex) and clinical relevance

\begin{tabular}{|c|c|c|c|c|c|c|}
\hline Signalment & \multicolumn{5}{|c|}{ Clinical relevance } & \multirow[b]{3}{*}{$P$ value } \\
\hline & \multicolumn{2}{|c|}{ Clinically irrelevant $(n=47)$} & \multicolumn{3}{|c|}{ Clinically relevant $(\mathrm{n}=28)$} & \\
\hline & & $\mathrm{n}$ & $\%$ & $\mathrm{n}$ & $\%$ & \\
\hline & Alpine Dachsbracke & 0 & $0.00 \%$ & 1 & $3.60 \%$ & \multirow{31}{*}{0.025} \\
\hline & American Staffordshire terrier & 2 & $4.30 \%$ & 4 & $14.30 \%$ & \\
\hline & Dogo Argentino & 2 & $4.30 \%$ & 0 & $0.00 \%$ & \\
\hline & Belgian Shepherd & 0 & $0.00 \%$ & 1 & $3.60 \%$ & \\
\hline & Bernese mountain dog & 1 & $2.10 \%$ & 2 & $7.10 \%$ & \\
\hline & Bichon Frise & 1 & $2.10 \%$ & 0 & $0.00 \%$ & \\
\hline & Dogue de Bordeaux & 1 & $2.10 \%$ & 0 & $0.00 \%$ & \\
\hline & Cane Corso & 0 & $0.00 \%$ & 1 & $3.60 \%$ & \\
\hline & Dobermann & 1 & $2.10 \%$ & 0 & $0.00 \%$ & \\
\hline & English bulldog & 1 & $2.10 \%$ & 1 & $3.60 \%$ & \\
\hline & English Cocker Spaniel & 1 & $2.10 \%$ & 0 & $0.00 \%$ & \\
\hline & Dachshund & 1 & $2.10 \%$ & 0 & $0.00 \%$ & \\
\hline & Istrian short-haired hound & 0 & $0.00 \%$ & 1 & $3.60 \%$ & \\
\hline \multirow{18}{*}{ Breed } & Mixed breeds & 19 & $40.40 \%$ & 4 & $14.30 \%$ & \\
\hline & Labrador retriever & 1 & $2.10 \%$ & 4 & $14.30 \%$ & \\
\hline & Maltese & 3 & $6.40 \%$ & 0 & $0.00 \%$ & \\
\hline & Dutch Shepherd & 1 & $2.10 \%$ & 0 & $0.00 \%$ & \\
\hline & German boxer & 2 & $4.30 \%$ & 1 & $3.60 \%$ & \\
\hline & German shepherd & 3 & $6.40 \%$ & 0 & $0.00 \%$ & \\
\hline & German Shorthaired Pointer & 0 & $0.00 \%$ & 1 & $3.60 \%$ & \\
\hline & Wire Fox Terrier & 1 & $2.10 \%$ & 1 & $3.60 \%$ & \\
\hline & Parson Jack Russel & 0 & $0.00 \%$ & 1 & $3.60 \%$ & \\
\hline & Miniature Pinscher & 1 & $2.10 \%$ & 0 & $0.00 \%$ & \\
\hline & Bull Terrier & 1 & $2.10 \%$ & 0 & $0.00 \%$ & \\
\hline & Standard Poodle & 1 & $2.10 \%$ & 0 & $0.00 \%$ & \\
\hline & Rottweiler & 0 & $0.00 \%$ & 1 & $3.60 \%$ & \\
\hline & Standard Schnauzer & 1 & $2.10 \%$ & 1 & $3.60 \%$ & \\
\hline & Rough Collie & 0 & $0.00 \%$ & 1 & $3.60 \%$ & \\
\hline & Tornjak & 1 & $2.10 \%$ & 0 & $0.00 \%$ & \\
\hline & West Highland White Terrier & 1 & $2.10 \%$ & 1 & $3.60 \%$ & \\
\hline & Golden Retriever & 0 & $0.00 \%$ & 1 & $3.60 \%$ & \\
\hline Age (years) & Median (IQR) & \multicolumn{2}{|c|}{$10.0(8.0-12.0)$} & \multicolumn{2}{|c|}{$9.0(8.0-11.0)$} & 0.388 \\
\hline \multirow{2}{*}{ Gender } & Male & 20 & $42.60 \%$ & 11 & $39.30 \%$ & \multirow{2}{*}{0.813} \\
\hline & Female & 27 & $57.40 \%$ & 17 & $60.70 \%$ & \\
\hline
\end{tabular}

IQR: interquartile range 
M. Crnogaj et al.: Comparison of spleen fine needle fenestration biopsy diagnoses in dogs

Table 2. Ultrasonographic findings and cytological diagnoses in dogs

\begin{tabular}{|c|c|c|c|c|c|c|}
\hline & & \multicolumn{4}{|c|}{ Clinical relevance } & \multirow[b]{3}{*}{$\mathrm{P}$ value } \\
\hline & & \multicolumn{2}{|c|}{$\begin{array}{l}\text { Clinically irrelevant } \\
(\mathrm{n}=47)\end{array}$} & \multicolumn{2}{|c|}{$\begin{array}{l}\text { Clinically irrelevant } \\
(\mathrm{n}=28)\end{array}$} & \\
\hline & & $\mathrm{n}$ & $\%$ & $\mathrm{n}$ & $\%$ & \\
\hline \multirow{4}{*}{$\begin{array}{l}\text { Spleen } \\
\text { heterogeneity }\end{array}$} & Homogeneous & 15 & $31.90 \%$ & 9 & $32.10 \%$ & \multirow{4}{*}{0.010} \\
\hline & $\begin{array}{l}\text { Homogeneous to mildly } \\
\text { heterogenous }\end{array}$ & 23 & $48.90 \%$ & 7 & $25.00 \%$ & \\
\hline & Heterogenous & 9 & $19.10 \%$ & 7 & $25.00 \%$ & \\
\hline & Patchy echo texture "moth-eaten" & 0 & $0.00 \%$ & 5 & $17.90 \%$ & \\
\hline \multirow{4}{*}{$\begin{array}{l}\text { Echogenicity of } \\
\text { the lesion }\end{array}$} & Hypoechoic & 19 & $79.20 \%$ & 16 & $66.70 \%$ & \multirow{4}{*}{0.740} \\
\hline & Hyperechoic & 1 & $4.20 \%$ & 1 & $4.20 \%$ & \\
\hline & Isoechoic & 0 & $0.00 \%$ & 1 & $4.20 \%$ & \\
\hline & Mixed & 4 & $16.70 \%$ & 6 & $25.00 \%$ & \\
\hline \multirow{4}{*}{$\begin{array}{l}\text { Number of } \\
\text { lesions }\end{array}$} & No lesions & 22 & $46.80 \%$ & 4 & $14.30 \%$ & \multirow{4}{*}{0.004} \\
\hline & One lesion & 15 & $31.90 \%$ & 11 & $39.30 \%$ & \\
\hline & Multiple lesions & 9 & $19.10 \%$ & 7 & $25.00 \%$ & \\
\hline & $\begin{array}{l}\text { Small multiple lesions (patchy echo } \\
\text { texture "moth-eaten") }\end{array}$ & 1 & $2.10 \%$ & 6 & $21.40 \%$ & \\
\hline $\begin{array}{l}\text { Lesion size- } \\
\text { diameter }(\mathrm{cm})\end{array}$ & Median (IQR) & \multicolumn{2}{|c|}{$0.96(0.80-1.50)$} & \multicolumn{2}{|c|}{$1.50(0.90-4.00)$} & 0.042 \\
\hline \multirow{2}{*}{ Lesion margins } & Irregular & 8 & $34.80 \%$ & 10 & $41.70 \%$ & \multirow{2}{*}{0.766} \\
\hline & Regular & 15 & $65.20 \%$ & 14 & $58.30 \%$ & \\
\hline \multirow{2}{*}{ Spleen size } & Normal size & 23 & $48.90 \%$ & 14 & $50.00 \%$ & \multirow{2}{*}{1.000} \\
\hline & Enlarged & 24 & $51.10 \%$ & 14 & $50.00 \%$ & \\
\hline \multirow{13}{*}{$\begin{array}{l}\text { Cytologic } \\
\text { diagnoses }\end{array}$} & Epithelial neoplasm (carcinoma) & 0 & $0.00 \%$ & 2 & $7.10 \%$ & \multirow{13}{*}{$<0.001$} \\
\hline & Extramedullary hematopoiesis & 15 & $31.90 \%$ & 0 & $0.00 \%$ & \\
\hline & Hemorrhage & 0 & $0.00 \%$ & 1 & $3.60 \%$ & \\
\hline & Hemangiosarcoma & 0 & $0.00 \%$ & 2 & $7.10 \%$ & \\
\hline & Hematoma & 0 & $0.00 \%$ & 2 & $7.10 \%$ & \\
\hline & Histiocytic sarcoma & 0 & $0.00 \%$ & 2 & $7.10 \%$ & \\
\hline & Lymphoma & 0 & $0.00 \%$ & 12 & $42.90 \%$ & \\
\hline & Mast cell tumour & 0 & $0.00 \%$ & 1 & $3.60 \%$ & \\
\hline & Metastatic neoplasia & 0 & $0.00 \%$ & 2 & $7.10 \%$ & \\
\hline & Nodular hyperplasia & 15 & $31.90 \%$ & 0 & $0.00 \%$ & \\
\hline & Normal spleen cell population & 17 & $36.20 \%$ & 0 & $0.00 \%$ & \\
\hline & Sarcoma & 0 & $0.00 \%$ & 2 & $7.10 \%$ & \\
\hline & Suppurative inflammation & 0 & $0.00 \%$ & 2 & $7.10 \%$ & \\
\hline \multirow{2}{*}{$\begin{array}{l}\text { Cytologic } \\
\text { diagnosis } \\
\text { groups }\end{array}$} & Benign & 47 & $100.00 \%$ & 5 & $17.90 \%$ & \multirow{2}{*}{$<0.001$} \\
\hline & Malignant & 0 & $0.00 \%$ & 23 & $82.10 \%$ & \\
\hline
\end{tabular}

IQR: interquartile range 
M. Crnogaj et al.: Comparison of spleen fine needle fenestration biopsy diagnoses in dogs

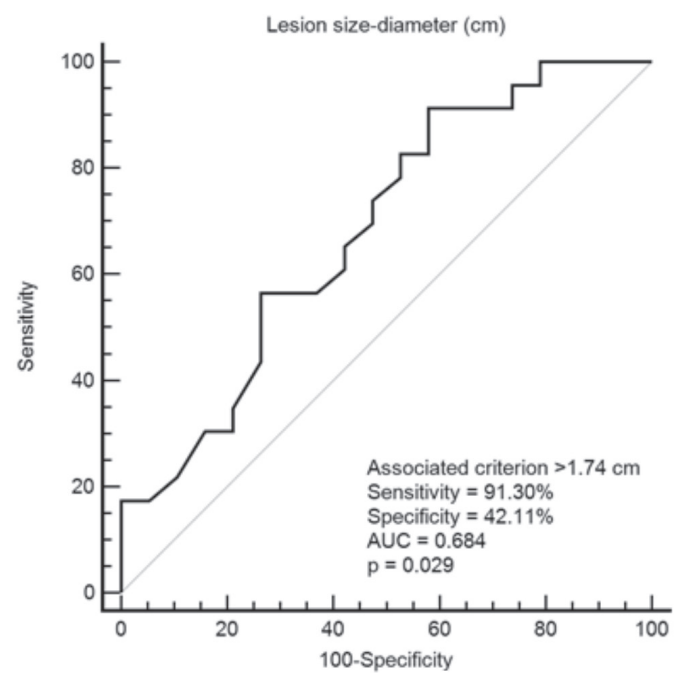

Fig. 1. ROC analysis of optimal lesion size diameter in predicting clinically relevant findings

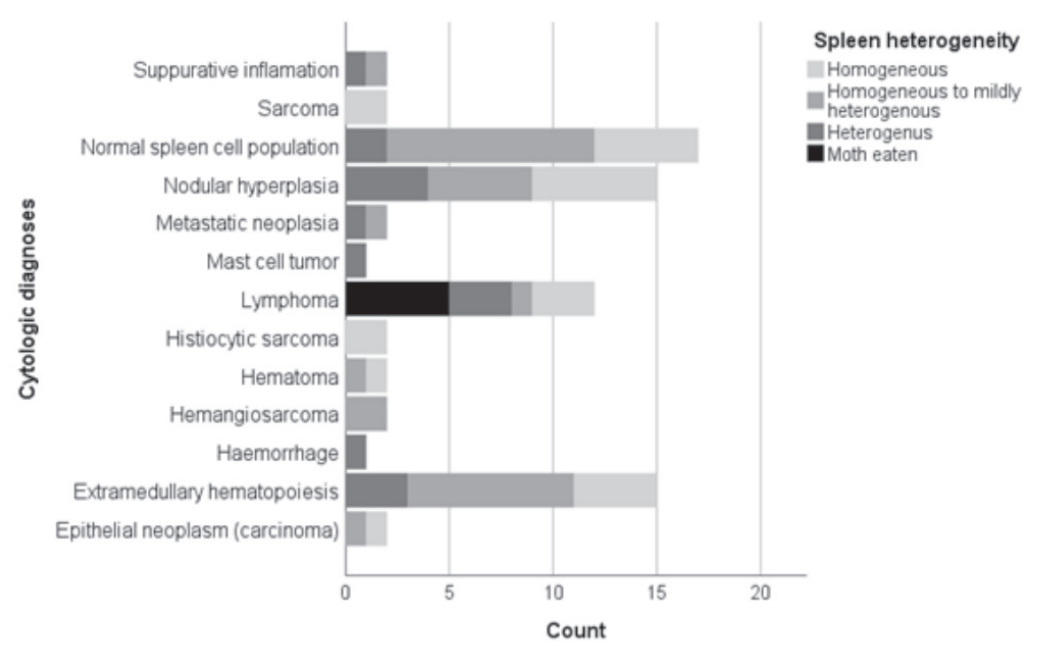

Fig. 2. Prevalence of ultrasonographic (spleen heterogeneity) vs. cytological findings. * Patchy echo texture: moth eaten

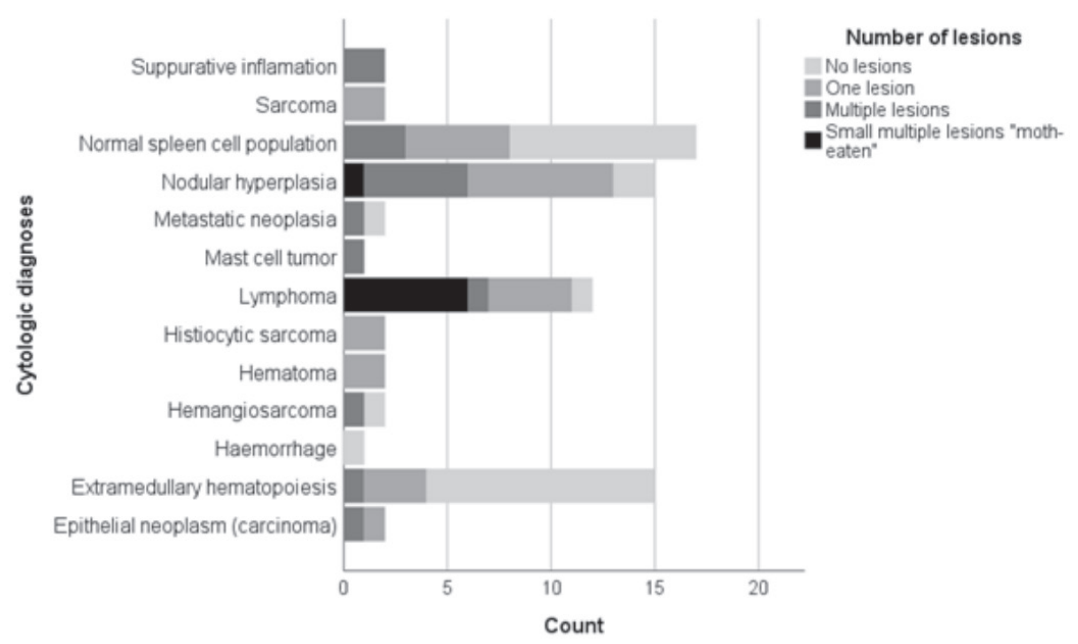

Fig. 3. Prevalence of ultrasonographic (spleen number of lesions) vs. cytological findings. * Patchy echo texture: moth eaten 
All dogs in the clinically relevant group had a malignant diagnosis except for one Labrador retriever whose cytological diagnosis was a hematoma. The most represented breeds in the clinically irrelevant group were: mixed breed (19/47; 40.4\%), Maltese (3/47; 6.4\%) and German shepherd $(3 / 47 ; 6.4 \%)$. There was a significant difference in breed prevalence between the groups studied $(\mathrm{P}=0.025)$.

There were no significant differences in age $(\mathrm{P}$ $=0.388$ ) between the study groups: the clinically irrelevant group (median 10.0 years; IQR 8.0-12.0 years) and the clinically relevant group (median 9 years; IQR 8.0-11.0 years).

There were more females than males in this study $(44 / 31 ; 58.7 \% / 41.3 \%)$, but there was no significant difference with respect to the clinically irrelevant/relevant groups $(\mathrm{P}=0.813)$ (Table 1$)$.

To obtain a more accurate complication rate, we included all the patients that underwent spleen FNFB procedures during the 6-year period (included and excluded cases $=130 \mathrm{dogs}$ ). There were no complications due to sedation. The complication rate due to bleeding around the spleen was $2 / 130(1.5 \%)$. All complications were reported in the clinically irrelevant group. Shortly after the procedure, a small amount of free fluid was noted around the spleen. The free fluid was reabsorbed in approximately one to two hours.

All dogs had at least one abnormal ultrasound finding and the majority of them had two or more abnormal findings simultaneously (Table 2). There was no significant difference in spleen size $(\mathrm{P}=$ $1.000)$, echogenicity of the lesion $(\mathrm{P}=0.740)$, and lesion margins $(\mathrm{P}=0.766)$ between the two groups studied. There was a significant statistical difference in splenic heterogeneity between the relevant and irrelevant groups in terms of homogeneous to slightly heterogeneous and patchy echo texture heterogeneity $(\mathrm{P}=0.010)$. There was a significant statistical difference in the number of lesions between the studied groups in patients who had small multiple lesions $(\mathrm{P}=0.004)$. Lesion size greater than $1.74 \mathrm{~cm}$ had the highest sensitivity and specificity values $(91.3 \%$ and $42.1 \%$, respectively) with a significant area under the curve (AUC) of
$0.68(\mathrm{P}=0.029)$ for predicting clinically relevant findings (Fig. 1).

According to the cytological results, $47 / 75$ of dogs $(62.6 \%)$ had clinically irrelevant findings (Table 2). Moreover, the most common cytological diagnosis in the irrelevant group was a normal splenocyte population $(17 / 47 ; 36.2 \%)$, followed by extramedullary hematopoiesis and nodular hyperplasia (15/47; $31.9 \%)$. Of the $28 / 75$ (37.3\%) dogs with a clinically relevant diagnosis, 23/28 $(82.1 \%)$ had a malignant diagnosis, while $2 / 28$ (7.1\%) had suppurative inflammation, and $3 / 28$ $(10.7 \%)$ had hemorrhage/hematoma. The most common cytological diagnosis in the clinically relevant group was lymphoma (12/28; 42.9\%;) (Table 2).

Figs 2 and 3 show the prevalence of ultrasonographic (heterogeneity of spleen and number of lesions) vs. cytologic findings.

\section{Discussion}

The increasing use of abdominal ultrasound as a diagnostic procedure in veterinary medicine has led to increased detection of splenic lesions. Minimally invasive procedures such as FNFB are used to avoid unnecessary surgical procedures. Even when FNFB is used, owners are reluctant to proceed with diagnostic procedures because of possible complications, such as sedation in older dogs and the possibility of hemorrhage/rupture of the spleen after FNFB. To obtain a more accurate complication rate, we included all the patients that underwent spleen FNFB procedures during a 6-year period (included and excluded cases $=130$ dogs). The complication incidence rate was $2 / 130$ $(1.5 \%)$. Complications were considered minimal, caused by bleeding which resolved within 2 hours, and were found in dogs with an irrelevant cytological diagnoses. Other studies have reported a complication rate of $0-2.6 \%$ of cases (LÉVEILLÉ et al., 1993; WATSON et al., 2011; GLIŃSKASUCHOCKA et al., 2013) for splenic FNFB, which is consistent with our study.

There were no significant age related differences $(\mathrm{P}=0.388)$ between the clinically irrelevant group compared to animals in the clinically relevant group, 
which is in agreement with several other studies (CHRISTENSEN et al., 2009; MALLINCKRODT and GOTTFRIED, 2011; LEYVA et al., 2018; YANKIN et al., 2020). In our study, there were more females $(44 / 75 ; 58.7 \%)$ compared to males $(31 / 75$; $41.3 \%)$, but there was no significant difference in terms of the clinically irrelevant/relevant groups $(P=0.813)$. Similar results have been reported in other studies (PRYMAK et al., 1988; JOHNSON et al. 1989; CHRISTENSEN et al., 2009; LEYVA et al., 2018; FIGUEIREDO et al. 2019; YANKIN et al., 2020). There was a significant difference in breed prevalence between the studied groups ( $P$ $=0.025)$. The most common breeds in this study were mixed breeds $(23 / 75 ; 30.6 \%)$, American Staffordshire terrier $(6 / 75 ; 8 \%)$, and Labrador Retriever $(5 / 75 ; 6.7 \%)$. The breeds most commonly represented in the clinically relevant group were the same: American Staffordshire terrier (4/28; $14.3 \%)$, mixed breed $(4 / 28 ; 14.3 \%)$, and Labrador Retriever $(4 / 28 ; 14.3 \%)$. All dogs in the clinically relevant group had a malignant diagnosis except for one Labrador retriever whose cytological diagnosis was a hematoma. Previous studies reported that mixed breed dogs, Golden Retrievers, Labrador Retrievers and German Shepherd were over-represented, which is similar to our results, with the exception of the American Staffordshire Terrier (JOHNSON et al. 1989; CHRISTENSEN et al., 2009; MALLINCKRODT and GOTTFRIED, 2011; CLEVELAND and CASALE, 2016; LEYVA et al., 2018; YANKIN et al., 2020).

The prevalence of clinically irrelevant cytological diagnoses versus clinically relevant diagnoses in the population of dogs admitted to the Clinic for internal medicine was 47/75 (62.7\%) versus $28 / 75$ (37.3\%). The most common cytological diagnosis in the clinically irrelevant group was: normal splenocyte population $(17 / 47 ; 36.2 \%)$, followed by extramedullary hematopoiesis $(15 / 47 ; 31.9 \%)$ and nodular hyperplasia $(15 / 47 ; 31.9 \%)$. This is in agreement with other studies that included all cases of splenomegaly or splenic nodules/ masses, and showed around 50\% prevalence of non-neoplastic disease (SPANGLER and KASS, 1998; BALLEGEER et al., 2007; CHRISTENSEN et al., 2009; CLEVELAND and CASALE, 2016;
MOKHYEON et al. 2018; FIGUEIREDO et al., 2019; YANKIN et al., 2020). The most common cytological diagnosis among the clinically relevant diagnoses was lymphoma $(12 / 28 ; 42.9 \%)$, regarding neoplastic pathology and hemorrhage/ hematoma $(3 / 28 ; 10.7 \%)$, and suppurative inflammation $(2 / 28$; $7.1 \%$ ) regarding non-neoplastic pathology, which is consistent with other studies on this topic in dogs (BALLEGEER et al., 2007; YANKIN et al., 2020). Hemangiosarcoma was the most commonly identified malignant neoplasm of the spleen in studies where splenectomy was performed in all dogs without prior fine needle aspiration biopsy (JOHNSON et al., 1989; MALLINCKRODT and GORRFRIED, 2011; FIGUEIREDO et al., 2019). The fact that hemangiosarcomas are more likely to rupture and bleed before diagnosis than other malignant splenic tumors might be the reason for the low frequency of hemangiosarcomas in our study $(2 / 28 ; 7.1 \%)$, and owners opted for splenectomy or euthanasia. All dogs included in our study had nonruptured splenic masses or nodules. Another reason may be that hemangiosarcoma is a highly vascularized neoplasm that is difficult to diagnose cytologically due to the low exfoliation of neoplastic cells and high blood contamination (FIGUEIREDO et al., 2019).

Our results showed no correlations in ultrasound variables, such as spleen size $(\mathrm{P}=1.000)$, lesion echogenicity $(\mathrm{P}=0.740)$, and lesion margins ( $\mathrm{P}$ $=0.766)$, between the two groups studied. This is in agreement with the study by YANKIN et al. (2020) and in partial agreement with the study by MOKHYEON et al. (2018), where lesion margins correlated with the type of splenic tumors. We found clinical relevance in patients with small multiple lesions $(\mathrm{P}=0.004)$, when comparing the clinically irrelevant and clinically relevant groups. BALLEGEER et al. (2007) reported an association between multiple and single lesions and malignant and benign diseases, while YANKIN et al. (2020) presented an opposite report. The reason for the different results could be the classification, since the dogs with small multiple lesions were specifically separated out in our study and they were of great significance between the studied groups, while YANKIN et al. (2020) used a 
single lesion and multiple lesions classification. There was a significant statistical difference in splenic heterogeneity between the relevant and irrelevant groups in terms of homogeneous to mildly heterogenous and in patchy echo texture heterogeneity $(\mathrm{P}=0.010)$. YANKIN et al (2020) reported no difference in spleen heterogeneity between the studied groups. Alesion size greater than $1.74 \mathrm{~cm}$ had the highest sensitivity and specificity values $(91.3 \%$ and $42.1 \%)$ with a significant area under the curve (AUC) of $0.68(\mathrm{P}=0.029)$ for predicting clinically irrelevant findings. YANKIN et al. (2020) reported that the presence of splenic nodules $1-2 \mathrm{~cm}$ in diameter was significantly more common in dogs with clinically relevant splenic lesions. MOKHYEON et al. (2018) found that the maximum lesion size found on ultrasonography differed significantly between malignant and benign tumors.

Although this is a retrospective study, ultrasound, FNFB procedures and the examination of cytological samples were standardized and performed according to professional standards in all cases included. We found two possible limitation of our study, first: the lack of histological evaluation of the spleen for comparison and confirmation of the cytological findings, and second: the relatively small sample size.

\section{Conclusions}

On the basis of our results, splenic FNFB can be safely performed in dogs as it carries a low risk of development of complications in the form of hemorrhage/hemoabdomen. The prevalence of clinically irrelevant cytological diagnoses is higher than that of clinically relevant cytological diagnoses. The most common malignant diagnosis was lymphoma. Certain ultrasonographic findings, such as the patchy echo texture pattern, may arouse suspicion of the presence of a neoplastic disease in the form of lymphoma in dogs, but it is still necessary to confirm the suspicion with the FNFB procedure. The absence of this particular pattern does not rule out lymphoma. According to ROC analysis, lesion size greater than 1.74 increases the possibility of predicting clinically relevant findings, and FNFB should be considered.

\section{References}

BALLEGEER E. A., L. J. FORREST, R. M. DICKINSON, M. M. SCHUTTEN, F. A. DELANEY, K. M. YOUNG (2007): Correlation of ultrasonographic appearance of lesions and cytologic and histologic diagnoses in splenic aspirates from dogs and cats: 32 cases (2002-2005). J. Am. Vet. Med. Assoc. 230, 690-696.

DOI: $10.2460 /$ javma.230.5.690

CHRISTENSEN, N. I., P. J. CANFIELD, P. A. MARTIN, M. B. KROCKENBERGER, D. S. SPEILMAN, K.L. BOSWARD (2009): Cytopathological and histopathological diagnosis of canine splenic disorders. Aust. Vet. J. 87, 175-181.

DOI: 10.1111/j.1751-0813.2009.00421.X

CLEVELAND M. J., S. CASALE (2016): Incidence of malignancy and outcomes for dogs undergoing splenectomy for incidentally detected nonruptured splenic nodules or masses: 105 cases (2009-2013). J. Am. Vet. Med. Assoc. $248,1267-1273$

DOI: $10.2460 /$ javma.248.11.1267

FIGUEIREDO, R. S., C. MURAMOTO, T. H.FONTES, I. D. S. MENESES, P. G. S. CARDOSO, C. H. C. VIEIRA FILHO, A. ESTRELA-LIMA, T. C. PEIXOTO (2019): Lesions in 224 spleens of splenectomized dogs and evalution of alternative techniques for previous microscopic diagnosis. Pesq. Vet. Bras. 39 , 622-629.

DOI: 10.1590/1678-5150-pvb-6266

GLIŃSKA-SUCHOCKA, K., M. JANKOWSKI, K. KUBIAK, J. SPUZAK, S. DZIMIRA, J. NICPON (2013): Fine needle biopsy of abdominal organ in dogs-indications, contraindications and performance technique. Pol. J. Vet. Sci. $16,835-842$.

DOI: $10.2478 /$ pjvs-2013-0118

HANSON, J. A., M. PAPAGEORGES, E. GIRARD, M. MENARD, P. HEBERT (2001): Ultrasonographic appearance of splenic disease in 101 cats. Vet. Radiol. Ultrasound. 42, 441-445.

DOI: 10.1111/j.1740-8261.2001.tb00967.x

JOHNSON, K. A., B. E. POWERS, S. J. WITHROW, M. J. SHEETZ, C. R. CURTIS, R. H. WRIGLEY (1989): Splenomegaly in dogs. Predictors of neoplasia and survival after splenectomy. J. Vet. Intern. Med. 3, 160-166.

DOI: 10.1111/j.1939-1676.1989.tb03092.x

LEBLANC, C. J., L. L. HEAD, M. M. FRY (2009): Comparison of aspiration and nonaspiration techniques for obtaining cytologic samples from the canine and feline spleen. Vet. Clin. Pathol. 38, 242-246.

DOI: 10.1111/j.1939-165X.2009.00115.x

LEYVA, F. J., C. A. LOUGHIN, C. W. DEWEY, D. J. MARINO, M. AKERMAN, M. L. LESSER (2018): Histopathologic characteristics of biopsies from dogs undergoing surgery with concurrent gross splenic and hepatic masses: 125 cases (2012-2016). BMC Res. Notes. 11, 122-126.

DOI: $10.1186 / \mathrm{s} 13104-018-3220-1$ 
LÉVEILlÉ, R., B. P. PARTINGTON, D. S. BILLER, T. MIYABAYASHI (1993): Complications after ultrasoundguided biopsy of abdominal structures in dogs and cats. 246 cases (1984-1991). J. Am. Vet. Med. Assoc. 203, 413415.

MALLINCKRODT, M. J., S. D. GOTTFRIED (2011): Massto-splenic volume ratio and splenic weight as a percentage of body weight in dogs with malignant and benign splenic masses: 65 cases (2007-2008). J. Am. Vet. Med. Assoc. 239, 1325-1327.

DOI: $10.2460 /$ javma.239.10.1325

MOKHYEON, L., J. PARK, C. HOJUNG, L. HAEBEOM, M. J. SEONG (2018): Presurgical assessment of splenic tumors in dogs: a retrospective study of 57 cases (20122017). J. Vet. Sci. 19, 827-834.

DOI: $10.4142 /$ jvs.2018.19.6.827

PRYMAK, C., LJ. MCKEE, M. H. GOLDSCHMIDT, L.T. GLICKMAN (1988): Epidemiologic, clinical, pathologic, and prognostic characteristics of splenic hemangiosarcoma and splenic hematoma in dogs: 217 cases (1985). J. Am. Vet. Med. Assoc.193, 706-712.

RAMIREZ, S., J. P. DOUGLASS, I. D. ROBERTSON (2002): Ultrasonographic features of canine abdominal malignant histiocytosis. Vet. Radiol. Ultrasound. 43, 167-170.
RASKIN, R. E., D. J. MEYER (2016): Canine and Feline Cytology - A Color Atlas and Interpretation Guide. $3^{\text {rd }}$ ed. Elsevier, USA, pp. 16-451. DOI: $10.1111 / \mathrm{j} .1740-8261.2002 . t b 01664 . \mathrm{x}$

SPANGLER, W. L., P. H. KASS (1998): Pathologic and prognostic characteristics of splenomegaly in dogs due to fibrohistiocytic nodules: 98 cases. Vet. Pathol. 35, 488-498. DOI: $10.1177 / 030098589803500603$

WATSON, A. T., D. PENNINCK, J. S. KNOLL, J. H. KEATING, J. SUTHERLAND-SMITH (2011): Safety and correlation of test results of combined ultrasound-guided fine needle aspiration and needle Core biopsy of the canine spleen. Vet. Radio. Ultrasound. 52, 317-322.

DOI: $10.1111 /$ j.1740-8261.2010.01778.x

YANKIN, I., S. NEMANIC, S. FUNES, H. DE MORAIS, E. GORMAN, C. RUAUX (2020): Clinical relevance of splenic nodules or heterogeneous splenic parenchyma assessed by cytologic evaluation of fine-needle samples in 125 dogs (2011-2015). J. Vet. Intern. Med. 34, 125-131. DOI: $10.1111 /$ jvim. 15648

Received: 1 July 2021

Accepted: 31 July 2021

\section{CRNOGAJ, M., I. ŠMIT, V. MRLJAK, S. DOŠEN, M. HOHŠTETER, I. KIŠ, D. GRDEN, M. BRKLJAČIĆ, J. GOTIĆ: Klinička korelacija između nalaza dobivenih fenestracijskom biopsijom slezene psa uz pomoć tanke igle i promjena slezene opaženih ultrazvukom. Vet. arhiv 91, 537-546, 2021.}

\section{SAŽETAK}

Medicinski kartoni iz baze podataka (od ožujka 2016. do ožujka 2021.) Veterinarskog fakulteta Sveučilišta u Zagrebu pretraženi su kako bi se utvrdila učestalost i klinička važnost citoloških dijagnoza uzoraka dobivenih fenestracijskom biopsijom tankom iglom (FBTI) slezene pasa s ultrazvučno vidljivim promjenama. Sedamdeset i pet pasa podijeljeno je u dvije skupine s obzirom na kliničku važnost dijagnoze: klinički relevantna i irelevantna skupina. Incidencija klinički relevantnih dijagnoza bila je 28/75 (37,3\%), s tim da su zloćudni tumori bili najzastupljeniji $(23 / 28 ; 82,1 \%)$, a nakon njih krvarenje/hematom $(3 / 28 ; 10,7 \%)$ te gnojna upala $(2 / 28 ; 7,1 \%)$. Najčešći je zloćudni tumor bio limfom (12/28; 42,9 \%). Nije zabilježena korelacija između ultrazvučnih promjena i klinički relevantne citološke dijagnoze, osim u slučajevima lezija pjegave ehostrukture $(\mathrm{P}=0,010)$. Lezije veće od $1,74 \mathrm{~cm}$ imale su najveće vrijednosti osjetljivosti/specifičnosti $(91,3 \% ; 42,1 \%$ ), sa znatnom površinom ispod krivulje (AUC) 0,68 (P= $0.029)$ za predviđanje klinički važnih nalaza. Stopa komplikacija vezana uz krvarenje nakon zahvata bila je 2/130 (1,5

\%). Zaključno, FBTI slezene siguran je zahvat jer nosi mali rizik od razvoja komplikacija. Specifični ultrazvučni nalaz poput lezija pjegave ehostrukture može povećati sumnju na prisutnost neoplastične bolesti poput limfoma. Prema ROC analizi lezije veće od $1,74 \mathrm{~cm}$ povećavaju mogućnost predviđanja klinički relevantnih nalaza.

Ključne riječi: pas; ultrazvuk; slezena; fenestracijska biopsija tankom iglom; citologija 